\title{
HULLADÉKOK MINTAVÉTELEZÉSE ÉS MINTAVÉTELEZÉSI MÓDSZEREK BEMUTATÁSA
}

\author{
Romenda Roland \\ tudományos segédmunkatárs, Miskolci Egyetem \\ Nyersanyagelökészitési és Környezeti Eljárástechnikai Intézet \\ 3515 Miskolc, Miskolc-Egyetemváros, e-mail: ejtrom@uni-miskolc.hu \\ Nagy Sándor \\ egyetemi docens, Miskolci Egyetem \\ Nyersanyagelőkészitési és Környezeti Eljárástechnikai Intézet \\ 3515 Miskolc, Miskolc-Egyetemváros, e-mail: sandor.nagy@uni-miskolc.hu \\ Faitli József \\ egyetemi docens, Miskolci Egyetem \\ Nyersanyagelőkészitési és Környezeti Eljárástechnikai Intézet \\ 3515 Miskolc, Miskolc-Egyetemváros, e-mail: jozsef.faitli@uni-miskolc.hu
}

\begin{abstract}
Absztrakt
A hulladékkezelök egyik adatszolgáltatási kötelezettsége - a hivatali szervek felé - a telephelyre bekerülő hulladékok mennyiségének és összetételének közlése. Utóbbi feladatot mintavételezéssel és az összetételre irányuló analizissel lehet kielégiteni, amelyet többnyire erre a célra specializálódott cégek végeznek. A mintavételezésböl és analizisböl származó adatok felhasználhatóak a különféle feldolgozó rendszerek technológiai tervezésére, a meglévö rendszerek hatékonyságának ellenőrzésére, módositására vagy egyéb, a hulladékok energetikai vagy anyagában történö hasznositásával, feldolgozásával kapcsolatos kutatásokra. Mivel mindezen területeket nem lehet egyfajta hulladékelemzési szabvánnyal megoldani, ezért különbözö módszerek alkalmazására van szükség. A tanulmány a szerzők és korábbi szerzőtársainak eredményeit és megállapitásait mutatja be néhány projekten keresztül.
\end{abstract}

Kulcsszavak: hulladékgazdálkodás, mintavételezés, hulladékanalizis, hulladékok összetétele

\begin{abstract}
One of the obligation of a waste management company is to report the inspector offices about the amount and composition of waste entering the company site. The latter task can be solved by sampling and compositional analysis, which is mostly performed by companies specializing in this purpose. However, data from sampling and analysis can be used for the technological design of various processing systems, the control and modification of the efficiency, or other research related to the processing or recovery of waste in energy or material. As not all of these areas can be solved by a single waste analysis standard, different methods need to be used. The study presents the results and conclusions of the authors and their former co-authors through some projects.
\end{abstract}

Keywords: waste management, sampling, waste analyse, composition of waste 


\section{Bevezetés}

Magyarország hulladékgazdálkodási rendszere a 2000-es évektől kezdett el igazán fejlődni, mikor is az Uniós csatlakozása előtt az ISPA program keretében átfogó környezetvédelmi beruházások és felmérések segítették hazánk felzárkózását hulladékkezelés és ártalmatlanítás terén [3]. Az azóta hozott intézkedéseknek köszönhetően, bár folyamatosan csökkent a hulladékok lerakással történő ártalmatlanításának aránya a többi kezelési módhoz képest, mégis az egyre növekvő környezettudatos gondolkodás, valamint az Európai Unió új, 2018/851 irányelvének hatására ezen arány további csökkentésére van szükség. E szerint 2030-ra a hulladéklerakás fokozatos csökkentése mellett a 10\% alatti deponálási hányadot és a keletkezett hulladékmennyiség legalább 65\%-ának újrahasznosítását-komposztálását tüzte ki célul [4][5]. Ez még a korábban nevesített „fejlett” országok, - nem beszélve a „lerakó” és „fejlődő" országokról - számára is igen komoly kihívás. Az 1. ábra az európai hulladékgazdálkodás fejlődését mutatja [13]. Az 1. ábra két úgynevezett háromszög diagramot mutat. A háromszög egy-egy szárán a három alapvető hulladékkezelési opció (lerakás, égetés, komposztálás - újrahasznosítás) százalékos aránya van ábrázolva. Természetesen ezek összege egy adott pontban $100 \%$. Az országok nagy része1995-ben még főleg lerakással kezelte a kommunális hulladékokat, néhány ország pedig kb. $30-30 \%$ égetést és komposztálás - újrahasznosítást alkalmazott.
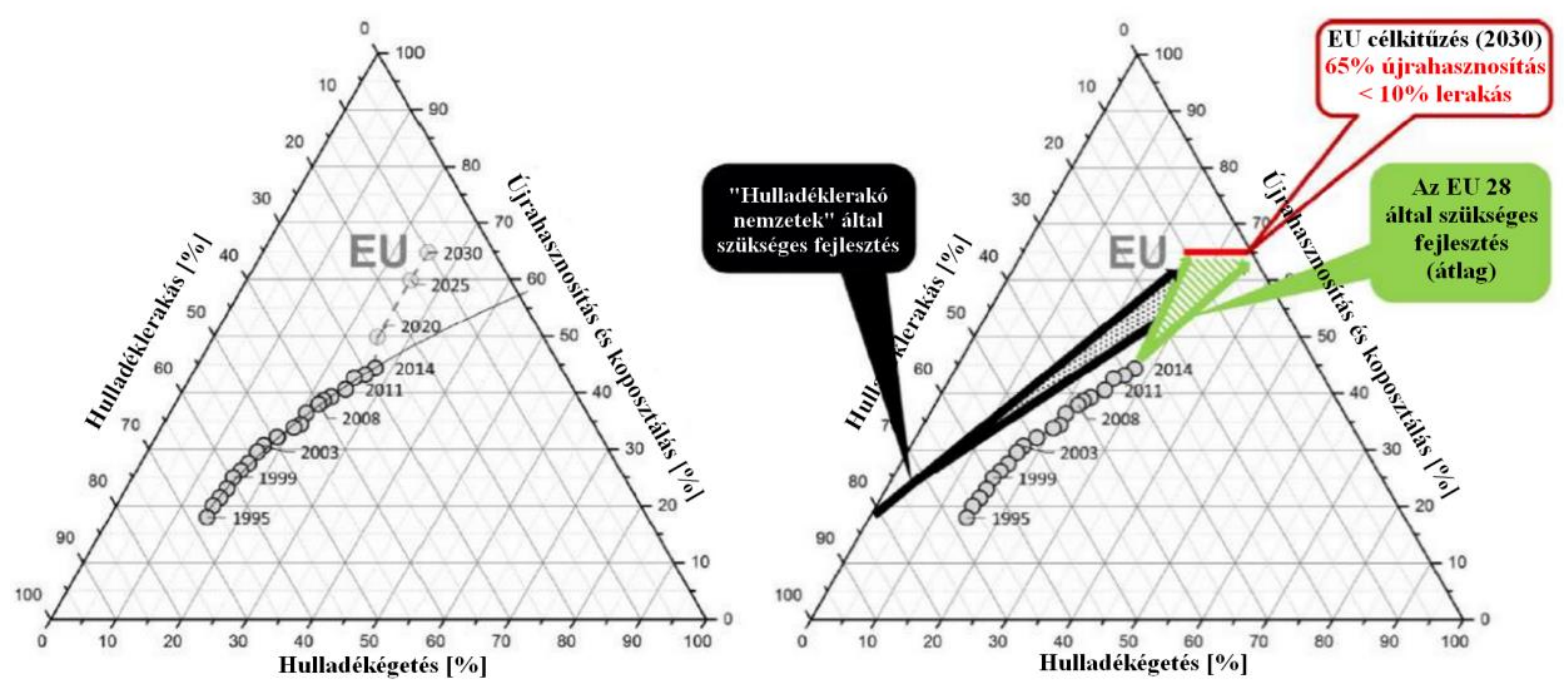

1. ábra. Az EU hulladékkezelési módjainak alakulása és a kitüzött célok [13]

\section{Hulladékok jellemzése}

Magyarországon a hulladékok jellemzését az MSZ 21420-as szabványcsoport foglalja össze, mely 32 részből áll és kitér a hulladékok fizikai, kémiai és biológia analízisének valamennyi részterületére. Ezen szabványok közül az MSZ 21420-28, „Települési szilárd hulladékok vizsgálata. Mintavétel” és az MSZ 21420-29, „Települési szilárd hulladékok vizsgálata. A minta előkészítése, az anyagi összetétel meghatározása anyagfajtákra történő válogatás útján" címü részek tartalmazzák a TSZH általános fizikai összetételére vonatkozó vizsgálati módszereket. A 309/2014. (XII. 11.) Korm. rendelet a hulladékkal kapcsolatos nyilvántartási és adatszolgáltatási kötelezettségekről 5. melléklete alapján a hulla- 
dékkezelök kötelesek a tárgyévben a telephelyen (a hulladéklerakóban) lerakott települési hulladék összetételét megadni (mennyiségi arány \%) a szabványban említett 13 anyagkategória szerint. Ezen anyagkategóriák a következők [11][12]: biológiailag lebomló, papír, karton, kompozit, textil, higiéniai hulladék, müanyag, nem osztályozott éghető hulladék, üveg, fém, nem osztályozott éghetetlen hulladék, veszélyes hulladék, kis szemcseméretü hulladék (finom hulladék, $<20 \mathrm{~mm}$ ).

A szabvány a hulladékok analíziséhez egy $100 \mathrm{~mm}$-es és egy $20 \mathrm{~mm}$-es négyzetes nyílású szitát ír elö, amelyek legalább 1,2×1,2 méteres szitafelülettel rendelkeznek. A válogatás során továbbá egy legalább 10 gramm pontosságú mérleget kell használni az egyes anyagkategóriák tömegének meghatározására. A kiindulási tömeg, mely a $100 \mathrm{~mm}$-es szitára feladásra kerül, a települési szilárd hulladékok mintázása esetén el kell hogy érje az $500 \mathrm{~kg}$-ot. Emellett a szabvány több fogalmat is definiál, például a gyüjtőszektorokat, a felmérendő területeket, valamint a nyers-, átlag-, kontroll és ellenminták közti különbségeket [12].

\section{Hulladékanalízisek}

A következőkben néhány korábbi hulladékanalízis kerül bemutatásra, melyeknél más-más szempontból történtek a vizsgálatok. Ezen vizsgálatok során látható lesz, hogy a fentebb említett szabvány szerinti elemzés nem lett volna kielégítő, hiszen a mintavételezésnek igazodnia kell a kitüzött célokhoz.

\subsection{Deponált hulladékok analízise}

A 21. században egyre inkább előtérbe kerülnek a másodnyersanyagok hasznosítása és azok felkutatása, hogy minél inkább a körforgásos gazdaság kerüljön elötérbe és a korábban kibányászott anyagok a lehető legtöbb alkalommal hasznosuljanak. Mivel a rekultivált lerakók nagy mennyiségben tartalmaznak nem bomló és már lebontott anyagokat, ezért ezek potenciális másodnyersanyag-forrásnak tekinthetöek. Ezen nyersanyagok kinyerésével csökken a hulladékok általi környezetterhelés, arányaiban véve kevesebb bányászatra van szükség, hiszen a már egyszer kibányászott anyagok kerülnek majd vissza a körforgásba, vagy akár energetikailag is hasznosítható nyersanyagra teszünk szert. 2017-ben a „Smart Ground” H2020-as projekt keretében a debreceni hulladéklerakónál történtek mintavételek, azzal a céllal, hogy a lerakóban található másodnyersanyag mennyiségét, illetve összetételének időbeli változásait megállapítsuk [7][8].

A mintavételezés a hulladéktest három különböző ütemének fúrásával történt. Erre azért volt szükség, mert a hulladéklerakás pillanatától számolva a hulladéktestben elkezdődtek a bomlási és konszolidációs folyamatok, melyek az idő múlásával változnak, így nem csak egy adott időpontban történt hulladék jellemzése történt. Az egyes fúrásokból egyenként 3-3 mintát különítettünk el, a $10 \mathrm{~m}$ mély és $0,8 \mathrm{~m}$ átmérőjü fúrások felső, középső és alsó szintjét, így összesen 9 minta ált rendelkezésre. A hulladékkezelő adatai alapján, megállapítható volt, hogy az egyes lerakási ütemek milyen időszakban voltak használatban, illetve az adott időszakokban milyen mennyiségben történt deponálás. Ezen adatok ismeretében az egyes mintákat kor szerint is összehasonlíthattuk [8]. A mintavételt és a rendelkezésre álló mintát a 2. ábra mutatja be.

Az elemzés során a szabvány szerinti 13 anyagkategória helyett csak 8 kategórát (papír, textil, müanyag éghetö, fém, inert, biológiai, $20 \mathrm{~mm}$ alatti) különböztettünk meg. A ,papír” anyagketgória tartalmazta a karton és tetrapack elemeket is, hiszen a hulladékból kinyert papír tartalmú anyagok anyagában történő hasznosítása már nem volt lehetséges, ezeket energetikai szempontból együtt kezeltük. 

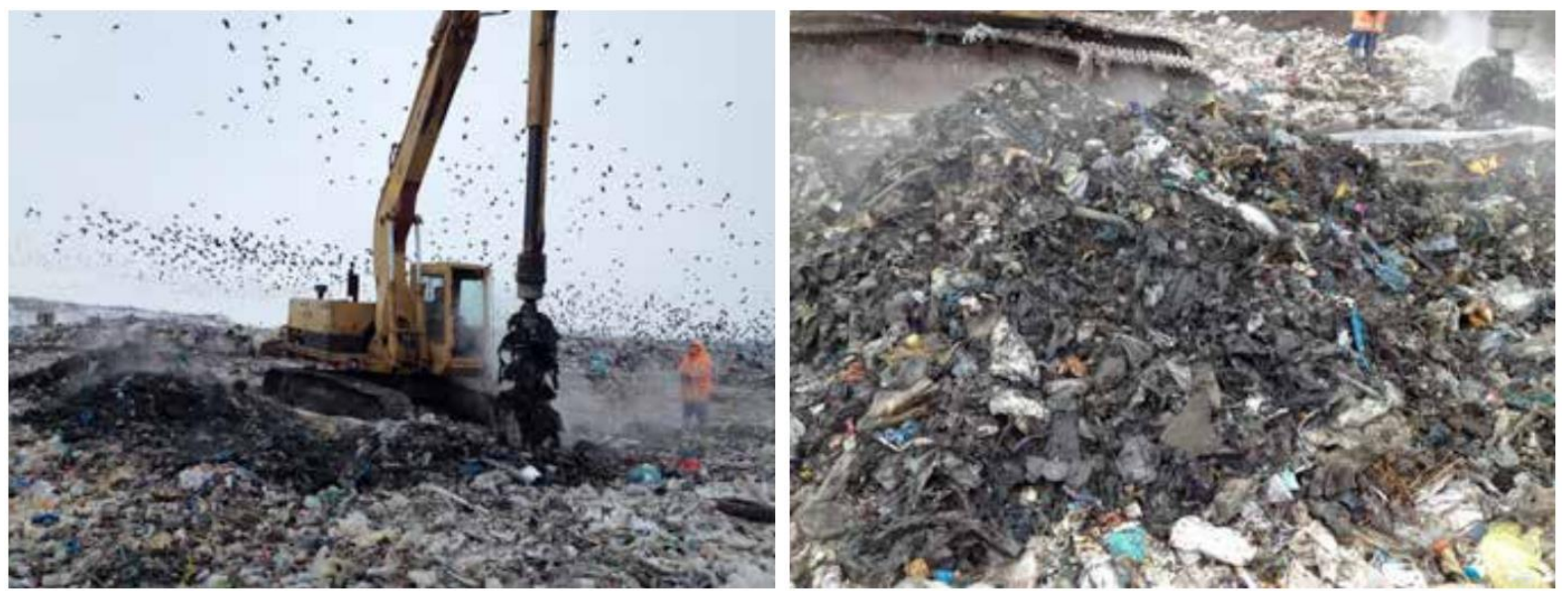

2. ábra. A „Smart Ground” projekt keretében történö mintavétel fúrással és a kivett minta

Ezen felül a hulladéktestben több éven keresztül, bomlásnak kitett papíranyagok már nagyrészt megkülönböztethtetlenek voltak egymástól. Ezen felül a szabvány szerinti kategóriák közül hiányzott a higéniai, üveg és veszélyes anyagkategória, amelyek mind valamely más kategóriába kerültek így besorolásra, annak függvényében, hogy eljárástechnikai szempontból a szétválasztás hogyan oldható meg. A szemcsméretfrakciókat és az alkalmazott módszertant a 3. ábra mutatja be.

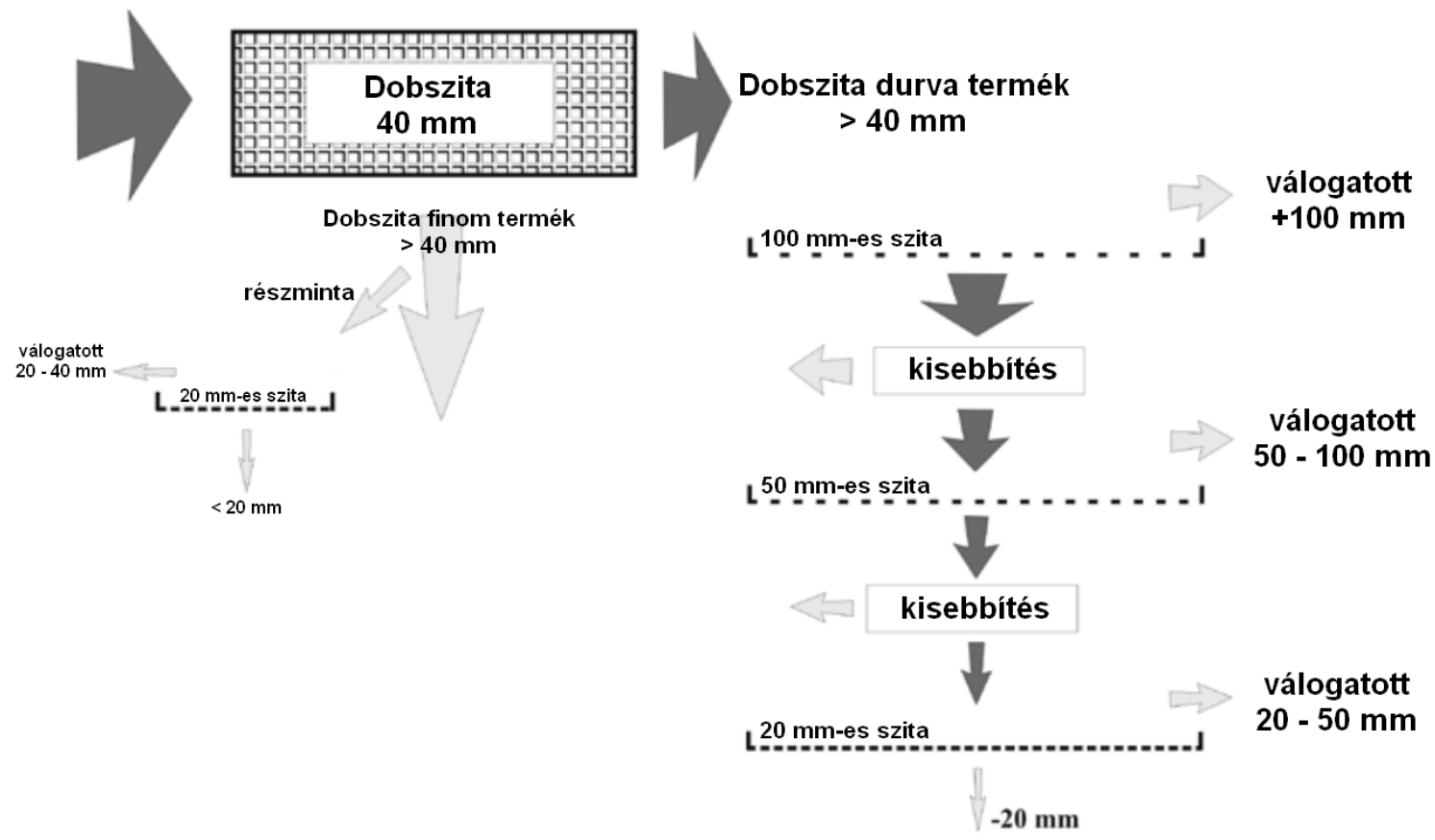

3. ábra. A „Smart Ground” projekt keretében alkalmazott elemzési metodika [8] 


\subsection{Analízis hulladékhasznosító üzem tervezésére}

Jelenleg Magyarország a hulladékok csak közel 30\%-át hasznosítja anyagában [10]. Ahhoz, hogy hazánk az EU által megfogalmazott célkitüzéseket elérje, a vegyesen gyüjtött kommunális hulladékok minél nagyobb arányú feldolgozása, valamint a már meglévő technológiák folyamatos fejlesztése és új hulladékhasznosító üzemek létesítése szükséges. A zalaegerszegi 3B Hungária Kft. egy GINOP projekt keretében új típusú hulladék feldolgozó berendezést tervezett a Miskolci Egyetem Nyersanyagelökészítési és Környezeti Eljárástechnikai Intézetével karöltve, melynek eredményeképpen egy olyan berendezés született, amely egy eszközben egyesíti három különböző eljárástechnikai alapberendezést, a mágneses és örvényáramú szeparátorokat, valamint a légáramkészüléket [6].

A berendezés tesztjeihez modellanyagot kellett elóállítani, illetve ismerni kellett a térségben begyüjtött hulladék anyagáramát. Mivel a berendezés örvényáramú szeparátort is tartalmazott, ezért a szabvány ismét nem volt elegendő, hiszen a 13 anyagkategória egyikét, a fémek, további két különböző kategóriára kellett osztani, a mágnesezhető (vas) fémekre, valamint a nem mágnesezhető (alumínium) fémekre. Napjainkban már a mágneses és örvényáramú szeparátorok szerves részét képezik a hulladékfeldolgozásnak, így e tekintetben a szabvány elavulttá vált. Ezen felül, az említett új típusú berendezés légáramkészüléket is tartalmazott, ami alapján a müanyagok további 3 kategóriára lettek osztva, fóliákra (2D-s múanyagok), alakos múanyagokra (3D-s müanyagok), és PET-re, mert az új üzem optikai szeparátort is tartalmazott.

A mára már elkészült hulladékhasznosító mü technológiai sorának elején egy darab, két különböző lyuknyílással rendelkező dobszita van, ezért a $100 \mathrm{~mm}$-es szitanyíláson túl egy $200 \mathrm{~mm}$-es szitát is alkalmaztunk. A végső szitasor végül 200, 150, 100, 75, 40 és 20 mm lett, amelynek köszönhetően egy részletes képet kaptunk a térség hulladékának összetételről [6].

\subsection{Országos hulladék-mintavételezési kampány}

A Nyersanyagelökészítési és Környezeti Eljárástechnikai Intézet 2017-18 folyamán egy téli és egy tavaszi országos hulladék-mintavételezési kampány elvégzésére kapott megbízást, amely kiemelt figyelmet fordított az élelmiszerhulladékokra, a hasznosítható másodnyersanyagokra és a csomagolóanyagokra. A kampányok során 7 régióban összesen 224 gyüjtőjármü került kiválasztásra és mintavételezésre. Az összetételi adatok megállapításán kívül az elemzés célja egy olyan analízis elvégzése, amelyben definiálunk néhány nevezetes paramétert és megvizsgáljuk, hogy ezek a paraméterek hogyan változtak település, régió, ill. a településeken belül a hulladékforrás típusa szerint [9][14].

Ez a mintavételezés a cikkben felsorolt három analízis közül a legrészletesebb volt. A szabványtól való eltérés, részletességében nagy, hiszen a 13 anyagkategória helyett összesen $2 \times 20$ kategória lett megkülönböztetve, amelyet az alábbi 1. táblázat mutat be.

Látható az 1. táblázatból, hogy az analízis részletessége messzemenően túlmutat a magyar szabványban foglaltakkal, amelynek több oka is van. Elöször is a biológiai anyagok felosztása a korábbi 2015/0275/COD EU direktíva (később 2018/851/EK irányelv) miatt vált szükségessé. Az Európai Unió az élelmiszerhulladékok csökkentését szorgalmazza, amely az élelmiszer pazarlásának visszaszorításától is függ, illetve a biológia úton lebontható anyag komposztálással történő hulladékhasznosítását is vizsgálja. A mủanyagok és fémek alcsoportokra történő bontása a már korábban ismertetett indokok miatt történt, a válogató berendezések terén tapasztalható fejlödés következménye. Végül, de nem utolsó sorban, a hulladékképződés egyik legnagyobb oka a túlzott csomagolóanyag használat. 
Ezért az 1. táblázatban bemutatott összes fó és alkategóriát csomagolóanyag tartalom szempontjából is vizsgáltunk. A hulladékkampány metodikáját a 4. ábra mutatja be.

1. táblázat. A magyar szabvány és az országos kampány anyagkategóriáinak összehasonlitása

\begin{tabular}{|c|c|c|}
\hline $\begin{array}{c}\text { Kategória } \\
\text { sorszáma }\end{array}$ & Magyar szabvány & Országos kampány \\
\hline 1 (a) & Biológiai & Élelmiszer \\
\hline (b) & & Nem ehető élelmiszer \\
\hline (c) & & Nem bontható élelmiszer \\
\hline (d) & & Egyéb biológiai \\
\hline 2 & \multicolumn{2}{|c|}{ Papír } \\
\hline 3 & \multicolumn{2}{|c|}{ Karton } \\
\hline 4 & \multicolumn{2}{|c|}{ Kompozit } \\
\hline 5 & \multicolumn{2}{|c|}{ Textil } \\
\hline 6 & \multicolumn{2}{|c|}{ Higiéniai } \\
\hline 7 (a) & Műanyag & Fólia (2D) \\
\hline (b) & & Alakos müanyag (3D) \\
\hline (c) & & PET \\
\hline 8 & \multicolumn{2}{|c|}{ Éghető } \\
\hline 9 & \multicolumn{2}{|c|}{ Üveg } \\
\hline $10(\mathrm{a})$ & Fémek & Vasfém \\
\hline (b) & & Alumínium \\
\hline (c) & & Réz \\
\hline 11 & \multicolumn{2}{|c|}{ Inert } \\
\hline 12 & \multicolumn{2}{|c|}{ Veszélyes } \\
\hline 13 & \multicolumn{2}{|c|}{ Finom $(<20 \mathrm{~mm})$} \\
\hline 14 & - & Idegen \\
\hline
\end{tabular}

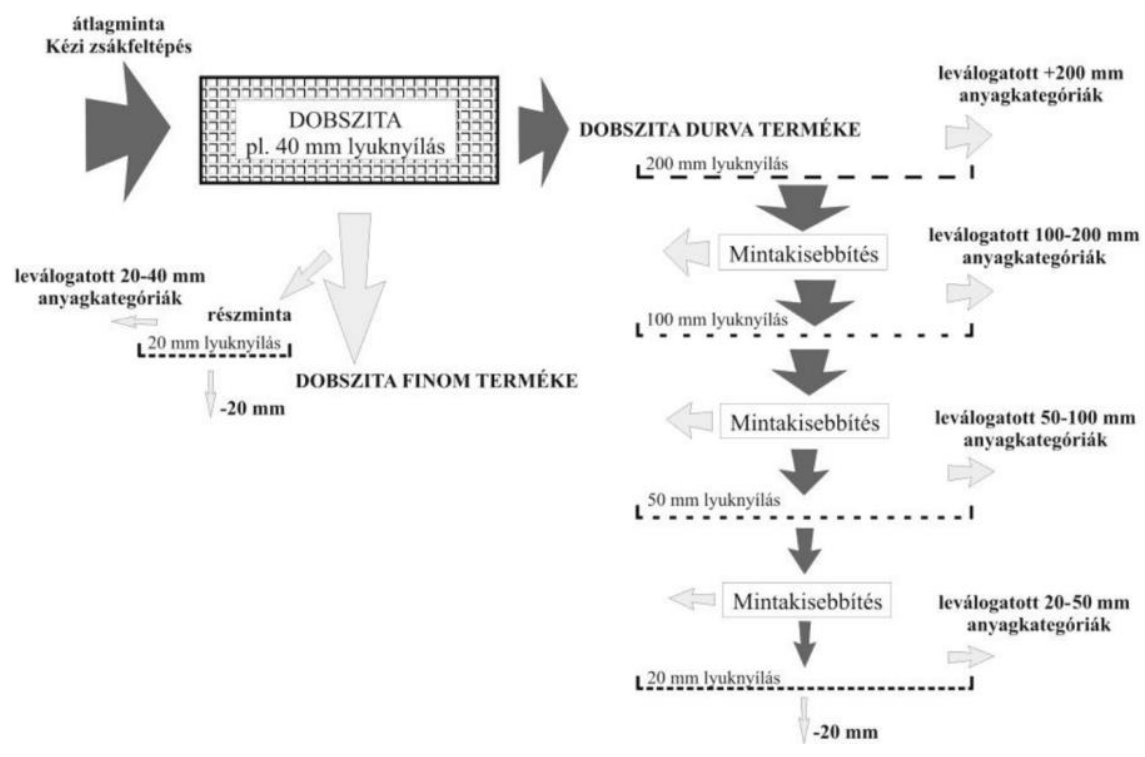

4. ábra. A hulladék-mintavételezési kampány során alkalmazott elemzési módszertan [14] 


\section{5. Összefoglalás}

Megállapítható, hogy a Magyarországon érvényben lévő MSZ 21420-28 és MSZ 21420-29 szabványok bár sok esetben elégséges, mégis az elmúlt 15 évben helyenként korrigálásra szorul. A technológia fejlődésének köszönhetően új válogató berendezések jelennek meg a hulladékgazdálkodásban, amelyek tervezéséhez szükséges az adott régió hulladékának átfogó analízise.

Minden felsorolt esetben tapasztalható volt, hogy szabvány adja a mintavételezés gerincét, azonban fontos átgondolni, hogy az elemzésnek mi a valódi célja. Amennyiben szükséges a szabvány részletezhetö, azonban az ebben foglaltaktól kisebb részletességet nem szabad alkalmazni. Ennek tükrében a szabvány a minimum követelménynek tekinthetö.

\section{Köszönetnyilvánítás}

A cikkben ismertetett kutató munka az EFOP-3.6.1-16-2016-00011 jelü „Fiatalodó és Megújuló Egyetem - Innovatív Tudásváros - a Miskolci Egyetem intelligens szakosodást szolgáló intézményi fejlesztése" projekt részeként - a Széchenyi 2020 keretében - az Európai Unió támogatásával, az Európai Szociális Alap társfinanszírozásával valósul meg.

\section{Irodalom}

[1] 2012. évi CLXXXV. törvény ,a hulladékról”

[2] 309/2014. (XII. 11.) Korm. rendelet „a hulladékkal kapcsolatos nyilvántartási és adatszolgáltatási kötelezettségekröl"

[3] Állami Számvevőszék: Az ISPA támogatásból megvalósított környezetvédelmi programok ellenörzéséről, Jelentés 0469 (2005)

[4] EU, 2008, Directive 2008/98/EC of the European Parliament and of the Council of 19 November 2008 on waste and repealing certain Directives, OJ L 312, 22.11.2008, p. 3-30.

[5] EU: Directive (EU) 2018/851 of the European Parliament and of the Council of 30 May 2018 amending Directive 2008/98/EC on waste pp. 109-140. (2018)

[6] Faitli, J., Csőke, B., Romenda, R., Nagy, Z., Németh, Sz.: Developing the combined magnetic, electric and air flow (KLME) separator for RMSW processing, Waste Management \& Research $36: 9$ pp. 779-787. , 9 p. (2018), https://doi.org/10.1177/0734242X18770251

[7] Faitli, J., Nagy, S., Bokányi, L., Gombkötő, I., Romenda, R., Csőke, B., Vér, Cs., Kiss, T., Dolgosné, K. A., Barna, L.: Települési szilárd hulladéklerakók vizsgálata a későbbi hasznosítás érdekében, Biohulladék $11: 1$ pp. 21-26. , 6 p. (2017), ISSN 2062-8811

[8] Faitli, J., Nagy, S., Romenda, R., Gombkötő, I., Bokányi, L., Barna, L.: Assessment of a residual municipal solid waste landfill for prospective 'landfill mining', Waste Management \& Research 29 Oct. 2019 p. https://doi.org/10.1177/0734242X19881197

[9] Faitli, J., Romenda, R.: Detailed Sampling Protocol for the Analysis of Residual Municipal Solid Wastes, In: K., Moustakas; M., Loizidou (szerk.) Proceedings of the 7th International Conference on Sustainable Solid Waste Management, Herakleion, Görögország: Hellenic Mediterranean University, (2019) pp. 1-10. Paper: Session XXIII. paper 10. , 10 p.

[10] KSH Központi Statisztikai Hivatal: A települések infrastrukturális ellátottsága (2019)

[11] Magyar szabvány: MSZ 21420-28, 2005, Hulladékok jellemzése. 28. rész: Települési szilárd hulladékok vizsgálata. Mintavétel. 
[12] Magyar szabvány: MSZ 21420-29, 2005, Hulladékok jellemzése. 29. rész: Települési szilárd hulladékok vizsgálata. A minta előkészítése, az anyagi összetétel meghatározása anyagfajtákra történő válogatás útján.

[13] Pomberger, R., Sarc, R., Lorber, K. E.: Dynamic visualisation of municipal waste management performance in the EU using Ternary Diagram method. Waste Management 61. pp. 558-571. (2017) https://doi.org/10.1016/j.wasman.2017.01.018

[14] Vojtonovszki-Soltész, V., Faitli, J.: A hazánkban keletkező kommunális hulladékok település és régió szintü, ill. a hulladékforrás típusa szerinti jellemző összetétele, In: Gábor, Rákhely; Cecilia, Hodúr (szerk.) II. Sustainable Raw Materials Conference Book - International Project Week and Scientific Conference, Szeged, Magyarország: University of Szeged, (2019) pp. 272-280. 